\title{
FACTORS INFLUENCING INTERNATIONAL BEER TRADE
}

\author{
LILI JANTYIK, ÁrON TÖröK, ATTILA JÁMBOR \\ Corvinus University of Budapest \\ Department of Agricultural Economics and Rural Development \\ 1093 Budapest Fővám tér 8. \\ lili.jantyik@uni-corvinus.hu
}

\begin{abstract}
Beer has been presenting in human life for a long time. The oldest written proof of beer production, the "Monument Bleu", comes from Mesopotamia, the 3rd millennium BC and by this time brewing was regulated by law (Ulischberger, 1982). Nowadays, globalization liberates the markets and large brewing companies achieve tremendous growth. In 2016, trade value of beer made from malt was 13,8 billion USD, according to the UNComtrade (2019) data. The main exporter was Mexico with $27 \%$ share in total beer export, followed by three EU beer producers: Netherlands, Belgium and Germany with shares of $14 \%, 11 \%$ and $9 \%$, respectively. On the other side, beer import was even more concentrated: the USA represented 35\% of global beer import, followed by France and the United Kingdom (5-5\%), China (4.5\%) and Italy (4.3\%). In case of beer, domestic consumption largely determines the industry, because the largest producers are not the top exporters. Based on FAO (2019) data, in 2014, 28\% of global beer production was brewed in China, followed by the USA (the biggest importer - 13\%), and $8 \%$ was produced in Brazil. Germany and Mexico, the two main exporters, only had $5-5 \%$ of market shares in terms of global beer production.

In our study we measured competitiveness using the index of Symmetric Revealed Comparative Advantage (SRCA), calculated for all countries exporting beer in the period of 1988-2017. In order to identify factors influencing SRCA, we applied panel-data linear models by using feasible generalized least squares (FGLS). We used the following independent variables for the model: barley production, FDI (foreign direct investment) levels, population, per capita GDP, per capita beer consumption, beer export unit value, number of beers with geographical indications, EU membership (as a dummy variable) and beer production.
\end{abstract}

Keywords: beer, international trade, geographical indications

\section{INTRODUCTION}

Beer is one of the most commonly consumed alcoholic drink in the world and the beer industry is a relatively frequently researched topic. KARAGIANNIS ET AL., (2018) investigated the industry in Europe. They found that a significant part of the estimated markup is due to product differentiation, especially in Bavaria. Moreover, the profit margin was higher for large firms and increased over time. They also observed increasing returns to scale and average costs above marginal costs, so in the German brewing sector a high markup does not necessarily translate into a high profit margin. In the study of DREYER AND FEDOSEEVA (2016) and DREYER ET AL. (2017), they also investigated the German market. They examined when the German beer exporters apply the Pricing to Market (PTM) strategies. The exporters apply PTM for local-currency stabilization, on those markets where imports are very sensitive to exchange-rate changes. German beer exports are strongly dependent on policy variables such as the introduction of Euro and the partner country's membership in the EU. Fertő and Podruzsik (2016) examined the pattern and driving forces of Intra-industry Trade (IIT) in beer market using relative factor endowments and the integrated Helpman and Krugman model. The results showed a negative relationship between differences in capital-labour ratios and IIT, and also between impacts of distance and IIT. The outcomes also confirmed the increasing role of IIT for beer products within the enlarged EU. The estimations supporting the dominance of vertical- over horizontal-type trade. On Member States' level, Austria, France, Germany, Italy and the UK report the highest levels of IIT within the enlarged EU. Olper et al., 
(2012) also examined the beer industry in the European Union. With theory-driven gravity equation they found that the home bias in beer consumption is higher than in wine. The home bias in beer is widely attributable to the home market effect, which means the breweries are localized close to their consumers in order to minimize the high transport costs associated with beer exports. ZANOTTI ET AL., (2018) examined the relationship between competitiveness and operational and financial performance of firms in the European brewing industry. Their results show that the competitive construct of the industry is significantly related to the financial performance of companies, but not inevitably to the operational results, and the operational structure of the company does not necessarily provide significant relationship to the financial results of the enterprise. In a British study the beer consumption data and the estimated new price and cross price elasticities for on- and off-trade beer sales reflect falling overall beer sales and also the changing dynamic within the British market. The estimated price elasticities had additional consequences, especially the efficiency of UK customs and excise duties for on-trade draught beer and the imposition of a minimum price per unit of alcohol. According to the results, in order to increase tax revenue, additional duties on beer are likely to be contradictory as long-term beer demand is price elastic. (TOMLINSON AND BRANSTON, 2013)

Several beer trade related studies exist which examine the Trade Agreement between the USA and Canada. Econometric analysis shows that it has a large impact on many American agricultural export categories: almost all the consumer-oriented products (except wine and beer), five of the intermediate products, and four of the bulk products. According to the same study, American affiliate sales in Canada have stimulated American exports of consumer-oriented products and intermediate products (MUNIRATHINAM ET AL., (1998). MALONE AND LUSK (2018b) used a branded discrete choice experiment for beer. They found that perceptions substantially affect consumer choices. In the context of brand equity for beer brands, the perceived taste and brand familiarity were key determinants of choice. In the article of MALONE AND LUSK (2018a) they collected data in the United States to identify potential market segments through consumers' taste perceptions of various beer brands. Besides several marketing research methods they used cluster analysis to provide a description of how market segments are influenced by brand familiarity.

THOMÉ AND SOARES (2016) used very similar approach as in this paper. They also examined the international competitiveness and market structure with Revealed Comparative Advantage, Relative Position of Market, Hirschman-Herfindahl index and Net Export Index for the period of 2003-2012. Their results show a high concentration for both the import and export markets and the detainers of the largest shares are: the United States of America for imports and Mexico, the Netherlands, Belgium and Germany for exports. The actors in the market structure could be identified on the basis of exporters, importers and exporters by stressing their market position.

\section{MATERIAL AND METHOD}

In order to measure comparative advantages on international level, we calculated the Symmetric Revealed Comparative Advantage (SRCA) for all the countries trading with beer between 1988 and 2017. SRCA is a linear transformation of the Balassa index (B),

$$
\mathrm{B}_{\mathrm{ij}}=\left(\frac{X_{i j}}{X_{i t}}\right) /\left(\frac{X_{n j}}{X_{n t}}\right),
$$

where $x$ means export, $i$ indicates a given country, $j$ is for a given product, $t$ stands for a group of products and $n$ for a group of countries. It follows that revealed comparative advantage or disadvantage index of exports to reference countries can be calculated by 
comparing a given country's export share from its total export - in correlation with the focus country's export share in their total export.

$$
\mathrm{SRCA}=(\mathrm{B}-1) /(\mathrm{B}+1)
$$

To identify the factors influencing competitiveness of beer trade, we also run panel regression model with variables explained in Table 1 .

$S R C A=\alpha+\beta_{1} \log$ Barleyprod $_{i j}+\beta_{2} F D I_{i j}+\beta_{3} \log P o p_{i j}+\beta_{4} \log$ Gdppc $_{i j}+\beta_{5} \log$ Beerprod $_{i j}+$ $\beta_{6}$ eumember $_{i j}+\beta_{7}$ gibeer $_{i j}+\beta_{8}$ pccon $_{i j}+\beta_{9 t u v} v_{i j}+\varepsilon_{i j}$

Table 1 Variables included to the panel regression calculations

\begin{tabular}{|l|l|l|}
\hline \multicolumn{1}{|c|}{ Variable } & \multicolumn{1}{c|}{ Remark } & \multicolumn{1}{c|}{ Source } \\
\hline SRCA & dependent variable, normalized RCA index & $\begin{array}{l}\text { own composition based } \\
\text { on World Bank data }\end{array}$ \\
\hline logBarleyprod & logarithm of the barley production & FAOSTAT \\
\hline FDI & FDI income measured in current USD & World Bank \\
\hline logPop & logarithm of the population & World Bank \\
\hline logGdppc & logarithm of the GDP/capita & World Bank \\
\hline logBeerprod & logarithm of the beer production & FAOSTAT \\
\hline eumember & $\begin{array}{l}\text { dummy variable, }=1 \text { if the given country was the } \\
\text { member of the European Union in the given year }\end{array}$ & European Commission \\
\hline gibeer & $\begin{array}{l}\text { number of beers with geographical indications in } \\
\text { the DOOR database in the given year }\end{array}$ & European Commission \\
\hline pccon & per capita beer consumption & $\begin{array}{l}\text { World Health } \\
\text { Organization }\end{array}$ \\
\hline tuv & unit value of the beer export & FAOSTAT \\
\hline
\end{tabular}

\section{RESULTS}

The TOP10 countries based on their SRCA index of beer production are indicated in Table 2 .

Table 2 TOP10 countries with highest SRCA index for beer trade

\begin{tabular}{|l|c|}
\hline Country & average SRCA 1988-2017 \\
\hline Namibia & 0.93 \\
\hline Jamaica & 0.84 \\
\hline Mexico & 0.72 \\
\hline Netherlands & 0.66 \\
\hline Denmark & 0.62 \\
\hline Serbia & 0.60 \\
\hline Dominican Republic & 0.59 \\
\hline Ireland & 0.53 \\
\hline Croatia & 0.49 \\
\hline Belgium & 0.44 \\
\hline
\end{tabular}

Results of panel regression are summarized in Table 3. In general we can say that all the variables are statistically significant (mostly with $p<0.01$ ). 
Table 3 Results of the panel regression model

\begin{tabular}{ll}
\hline & SRCA \\
\hline logBarleyprod & -0.010 \\
& $(1.67)^{*}$ \\
FDI & 0.000 \\
& $(2.61)^{* * *}$ \\
logPop & -0.151 \\
& $(7.92)^{* * *}$ \\
logGdppc & -0.159 \\
& $(8.45)^{* * *}$ \\
logBeerprod & 0.118 \\
& $(6.87)^{* * *}$ \\
eumember & 0.284 \\
& $(8.84)^{* * *}$ \\
gibeer & 0.024 \\
& $(2.23)^{* *}$ \\
pccon & 0.053 \\
& $(4.77)^{* * *}$ \\
tuv & -0.077 \\
& $(3.22)^{* * *}$ \\
cons & 2.077 \\
& $(7.69)^{* * *}$ \\
$N$ & 1.536 \\
\hline \multirow{2}{*}{$* \mathrm{p}<0.1 ; * * \mathrm{p}<0.05 ; * * *$} & $\mathrm{p}<0.01$ \\
&
\end{tabular}

\section{CONCLUSION}

Revealed comparative advantages measured by SRCA seems to be high for all the most important exporting countries except Germany. Mexico and Netherlands were among the countries with the highest SRCA values indicating strong comparative advantages $(0.72$ and 0.66 respectively, calculated as an average of the period 1988-2017). However, the most relevant importers (except the United Kingdom) had comparative disadvantages in international beer trade.

The panel regression model also provided solid, statistically significant results (mostly with $\mathrm{p}<0.01$ ). Barley production had very marginal and negative effect on SRCA index, so the input can be purchased from international markets. FDI did not have a direct impact on competitiveness. The population and the purchasing power (GDP/capita) of the domestic market had a negative influence on beer competitiveness. It seems producers with higher per capita consumption were usually more successful in exporting. The EU membership also increased SRCA level. We also examined the role of the quality in the beer industry. Producing and exporting beer with geographical indications had positive influence on the exporting countries' comparative advantages. Export unit value is in negative correlation with competitiveness, so we can conclude that large quantities of average quality beers more relevant in competitiveness. We found that quantity of beer production strongly and positively influenced SRCA. Countries producing more beer can expect more success in the global market. 


\section{ACKNOWLEDGEMENTS}

This paper was supported by János Bolyai Research Scholarship of the Hungarian Academy of Sciences, by the ÚNKP-18-4 New National Excellence Program of the Ministry of Human Capacities and by the National Research, Development and Innovation Office projects of FK124800 and PD124791 'Economical and Social Impacts of Food Quality Schemes and Short Food Supply Chains in Hungary' and by the National Research, Development and Innovation Office Project No. 119669 'Competitiveness of Agriculture in International Trade: A Global Perspective'

\section{REFERENCES}

Dreyer, H., Fedoseeva, S. (2016): Gravity Models and Asymmetric Exchange Rate Effects: Insights from German Beer Exports. Agribusiness 32(2): 289-295. doi:10.1002/agr.21469

Dreyer, H., Fedoseeva, S., Herrmann, R. (2017): Gravity Meets Pricing to Market: What a Combined-Method Approach Tells Us on German Beer Exports and Pricing. Jahrbücher für Nationalökonomie und Statistik 237(4): 295-328. doi:10.1515/jbnst-20170106

FAO. (2019): FAOSTAT, Data, Crops Processed. Retrieved from http://www.fao.org/faostat/en/\#data/QD

FerTö, I., PODRuzsiK, S. (2016): Intra-industry Trade in the Beer Industry within the Enlarged European Union Brewing, Beer and Pubs (pp. 74-96).

Karagiannis, G., Kellermann, M., Proll, S., Salhofer, K. (2018): Markups and product differentiation in the German brewing sector. Agribusiness 34(1): 61-76. doi:10.1002/agr.21528

MALONE, T., LUSK, J. L. (2018a): If you brew it, who will come? Market segments in the US beer market. Agribusiness 34(2): 204-221. doi:10.1002/agr.21511

MALONE, T., LUSK, J. L. (2018b): An instrumental variable approach to distinguishing perceptions from preferences for beer brands. Managerial and Decision Economics 39(4): 403-417. doi:10.1002/mde.2913

Munirathinam, R., ReED, M. R., Marchant, M. A. (1998): Effects of the Canada-U.S. Trade Agreement on U.S. Agricultural Exports. International Food and Agribusiness Management Review, 1(3): 403-415.

OlPer, A., Curzi, D., Frisio, D. G., Raimondi, V. (2012): Home Bias in Consumption: A Comparison between Wine and Beer. Paper presented at the The Economics of Beer and Brewing: Selected Contributions of the 2nd Beeronomics Conference.

THOMÉ, K. M., SOARES, A. B. P. (2016): International market structure and competitiveness at the malted beer: from 2003 to 2012. Agricultural Economics (Zemědělská ekonomika) 61(4): 166-178. doi:10.17221/189/2014-agricecon

Tomlinson, P. R., BRAnston, J. R. (2013): The demand for UK beer: estimates of the long-run on- and off-trade beer price elasticities. Applied Economics Letters 21(3): 209214. doi:10.1080/13504851.2013.848022

UlischBerger, E. (1982): Sörivóknak való (I. Héra, Trans.). Mezőgazdasági Kiadó, Budapest.

UNCOMTRAdE. (2019): United Nations Commodity Trade Statistics Databas. Retrieved from https://comtrade.un.org/db/default.aspx

ZANOTTI, C., REYES, F., FERnANDEZ, B. (2018): Relationship between competitiveness and operational and financial performance of firms: An exploratory study on the European brewing industry. Intangible Capital 14(1). doi:10.3926/ic.1104 